\title{
Incidence of Physical Damage on Peach and Nectarine Skin Discoloration Development: Anatomical Studies
}

\author{
Carlos H. Crisosto, R. Scott Johnson, and Juvenal Luza \\ University of California, Kearney Agricultural Center, 9240 South Riverbend Avenue, Parker, CA 93648 \\ Kevin Day \\ Tulare County Cooperative Extension, Visalia, CA 93291
}

Additional index words. inking, abrasion, vibration damage, copigmentation, Prunus persica

\begin{abstract}
Skin discoloration (SD) formation in peach [Prunus persica (L.) Batsch] and nectarine [Prunus persica (L.) Batsch, var. nectarine] was related to physical damage (abrasion) to the fruit during fruit handling (harvest and hauling operations) within the orchard and during transport to the packinghouse. Vibration and rubbing treatments increased SD formation indicating that tissue damage is involved in SD formation. Anatomical studies comparing sound and SD-injured tissues done by scanning electron and light microscopy indicated that very-low-intensity physical damage could induce brown and/or black spots because of cell disruption in the epidermal and hypodermal layers. The fact that injury was specific to the exocarp tissues (cuticle, epidermis, and hypodermis), and that mesocarp tissue located below the exocarp cells remained sound and turgid, indicated that abrasion injury is associated with SD. Similar types of visible and anatomical injury characteristics were induced by a rubbing treatment, demonstrating that physical abrasion damage affecting just exocarp cells was enough to induce SD:
\end{abstract}

Skin discoloration or inking of peach and nectarine fruit has become a frequent problem in the past decade in California, as well as in other production areas. Although SD affects only the fruit's cosmetic appearance, this disorder causes considerable losses to the peach and nectarine industry each year. Of the fruit shipped to the New York market between 1972 and 1975, nearly 16\% of the peaches and 13\% of the nectarines showed some SD (Ceponis et al., 1987). The SD disorder appears as either dark (black staining), or dark brown, orange, or tan (brown discoloration) spots. It has been suggested that development of this disorder is associated with exogenous contamination occurring during packing operations (Baumgarder, 1985; Denny et al., 1986; Hopfinger, 1985; Hopfinger and Frecon, 1985; Ridley et al., 1976; Van Blaricom and Senn, 1967). However, an anatomical comparison between sound and damaged tissues has never been done. Despite the importance of the SD problem, few studies have been done to try to understand the SD development mechanism(s). Denny et al. (1986) hypothesized that fruit injury was a requirement for SD formation because it allowed iron ions to penetrate and complex with the pigments inside the cells. Thus, most of the available data supports the hypothesis that iron or high $\mathrm{pH}$ contamination during the packinghouse operation following physical injury is the cause of SD. Based on this information, most of the recommendations to control SD have focused on reducing metallic ion contamination and basic $\mathrm{pH}$ exposure during the packinghouse operation. Hudson and Christ (1981) advised that clean drying rollers need to be used during packing. Hopfinger (1985), in New Jersey, recommended reduction of iron concentration in the water used during the peach hydrocooling operation. Phillips (1988) reported that nearly $23 \%$ of the fruits of 'Elegant Lady' and ' $O$ ' Henry' had SD upon arriving at the packinghouse, suggesting that $\mathrm{SD}$ was related to transport injury.

In Mar. 1991, a survey was sent to peach and nectarine producers in the Central Valley of California to ascertain at which step

Received for publication 27 July 1992. Accepted for publication 16 Feb. 1993. This study was funded in part by a grant from the California Tree Fruit Agreement. We thank Craig Kaprielian, Kings Canyon Fruit Co., and Douglas Phillips, USDA (ret.), Fresno, for their helpful assistance. The cost of publishing this paper was defrayed in part by the payment of page charges. Under postal regulations, this paper therefore must hereby be marked advertisement solely to indicate this fact. during harvest and postharvest handling operations SD was first noted. Twenty-one percent of the respondents observed SD while the fruit were still on the trees, $26 \%$ while in the bins, $10 \%$ when it arrived at the packinghouse, $38 \%$ during the packing operations, and 5\% upon leaving the packinghouse (Crisosto et al., 1992).

Based on the lack of published information on SD development, we decided to determine where SD damage occurs during postharvest handling operations, and if physical damage is related to its development. This information is fundamental to understanding SD development and generating recommendations to reduce SD incidence for the stone fruit industry.

\section{Materials and Methods}

In all experiments, evaluation of skin discoloration (SD) was done by placing fruit samples in a room controlled at 20C (68F) and $80 \%$ RH for 3 days before SD evaluation. SD was determined by two methods: 1) percentages of individual fruit presenting SD symptoms, and 2) an aggregated SD index (AII) based on measurements of total fruit surface area affected by SD. AII was measured by using a $0.9-\mathrm{cm}$-diameter loop; a larger discolored area was counted as two or more, accordingly. Percentage of cull fruit according to the California Quality Standards (U.S. Dept. of Agriculture, 1987), which enforces that any fruit presenting a discolored area $20.9 \mathrm{~cm}$ in diameter should be rejected, was calculated.

Vibration damage. We examined the effect of vibration damage on SD susceptibility of four peach ('Flavorcrest', 'Red Top', 'Elegant Lady', and 'O'Henry') and two nectarine ('Fantasia' and 'Royal Giant') cultivars, mid- and late-season cultivars, growing under similar orchard management conditions at the Kearney Agricultural Center (KAC), Parlier, Calif. A random sample of 18 fruit for each of the three single-tree replications were used per each cultivar and subjected to the treatment. Fruit were gently hand-picked and packed into tray packs in the orchard and transported in the bin to the loading point within the orchard. From there, fruit were transported to the KAC Postharvest Laboratory (2 $\mathrm{km})$ for subsequent vibration and SD evaluations. The vibration test consisted of two treatments: fruit dipped in tap water $(\mathrm{pH} 7.3)$ for $2 \mathrm{~min}$ or fruit dipped in the water and followed by a vibration test $-20 \mathrm{~min}$ at $1.1 \mathrm{~g}$ acceleration and 6.4-mm stroke at 550 cycles/ 
Table 1. Effects of vibrational injury on percentage of nectarines and peaches showing skin discoloration.

\begin{tabular}{lcccccc}
\hline & \multicolumn{3}{c}{ Peaches } & \multicolumn{2}{c}{ Nectarines } \\
\cline { 2 - 6 } Treatment & Flavorcrest & Red Top & Elegant Lady & Fantasia & O'Henry & Royal Giant \\
\hline Dipped $^{y}$ only & $36.7 \mathrm{a}^{\mathrm{z}}$ & $26.7 \mathrm{a}$ & $33.3 \mathrm{a}$ & $33.3 \mathrm{a}$ & $20.0 \mathrm{a}$ & $30.0 \mathrm{a}$ \\
Dipped and vibrated $^{\mathrm{x}}$ & $93.3 \mathrm{~b}$ & $86.7 \mathrm{~b}$ & $100.0 \mathrm{~b}$ & $70.0 \mathrm{~b}$ & $73.3 \mathrm{~b}$ & $53.3 \mathrm{~b}$ \\
\hline
\end{tabular}

\footnotetext{
${ }^{\bar{z}}$ Mean separation within columns by the $\mathrm{F}$ test at $P \leq 0.05$. Each mean represents the average of three replications of 18 fruit.

'Dipped in tap water (pH 7.3) for $2 \mathrm{~min}$.

${ }^{\mathrm{x}}$ Vibration for $20 \mathrm{~min}$ at $1.1 \mathrm{~g}$ acceleration and $6.4-\mathrm{mm}$ stroke at $550 \mathrm{cycles} / \mathrm{min}$.
}

min, which simulated commercial transit conditions (Mitchell and Kader, 1992). After treatment, fruit were handled according to our SD evaluation test.

Abrasion damage. The effect of abrasion injury on SD development was studied on 'Flavorcrest', 'O'Henry', 'Elegant Lady', and 'Suncrest' peaches and 'Fantasia' nectarine growing at KAC. Four replications of 20 fruit each were used for each cultivar. Fruit at commercial maturity were picked at random from the tree and rubbed gently with a clean, dry washcloth, and then placed in a tray pack and carefully transported to $\operatorname{KAC}(2 \mathrm{~km})$ for later SD evaluations. Fruit anatomical observations of sound and rubbed skin tissues were also carried out.

SD disorder occurrence. SD occurrence during commercial harvest and postharvest handling was recorded on 'Flavorcrest', 'Elegant Lady', and 'O'Henry' peaches grown in the Traver area, Fresno County (an area with a history of SD occurrence). Samples were collected on three harvest dates for each cultivar and at three locations during harvest and transport: 1) directly from the tree and field-packed; 2) from bins, after bin filling and transport in the orchard to the loading point; and 3) from bins arriving at the packinghouse (after handling and transport to the packinghouse).

Four replications of 18 fruit were taken for each cultivar. Fruit samples were picked at random from three trees selected previously and marked. Fruit were tracked during routine harvest and collected at the three locations noted. After collection, fruit samples were placed carefully in tray packs, padded, and packed in the orchard before being transported to KAC $(36 \mathrm{~km})$ for subsequent SD evaluation.

Fruit pack-out was based on the USDA grades requirement (U.S. Dept. of Agriculture, 1987) that fruit with a discolored area $\geq 0.9 \mathrm{~cm}$ in diameter be rejected as culls.

Anatomical studies. Samples of sound and SD-injured tissues from peaches and nectarines were collected in the orchards and from the SD experiments. Comparisons were made between the stained spots (black and brown) and sound skin within the same fruit, or sound fruit vs. SD-injured fruit. Skin samples were cut into 4-mm square pieces from the cheek of the fruit. The pieces were immediately subjected to a mild vacuum for $30 \mathrm{~min}$. Samples for light microscopy (LM) were fixed in a $\mathrm{pH} 7.0,4 \%$ glutaraldehyde solution containing $0.2 \mathrm{M}$ dipotassium phosphate and $0.1 \mathrm{M}$ citric acid monohydrate. Fixed samples were washed, dehydrated, sectioned, and infiltrated with glycol methacrylate resin (DuPontSorvall; Wilmington, Dela., modified from O'Brien and McCully, 1981), as reported previously by Luza et al. (1992). To analyze general cellular morphology, samples were stained with $0.5 \%$ toluidine blue in $0.15 \mathrm{M} \mathrm{K}_{2} \mathrm{PO}_{4}, 0.5 \%$ safranin in $0.2 \mathrm{M}$ Tris. $\mathrm{HCl}$, and counter-stained with calcofluor white MR2 (American Cyanamide Co., Bond Brook, N.J.) (Hughes and McCully, 1975). For cuticle observations, slides were stained with nile red in $100 \%$ acetone and mounted in glycerol. The different staining procedures provided complementary information on epidermal, hypodermal, and mesocarpal morphology of sound and injured tissue.
Nile red induced a bright fluorescent red pigment in fatty substances, providing information about the cuticle's general appearance and thickness. In samples stained with calcofluor, cellulose walls fluoresced intensely while cytoplasmic components were completely unstained. Calcofluor discloses differences in cell wall shape and degree of cell separation. Toluidine blue-safranin is a high-contrast stain for revealing general cytological structure. All fluorescence observations were carried out on a Zeiss microscope equipped for epi-illumination with a HBO 50 mercury lamp. Photomicrographs were taken on Kodak Pan-X film for bright field and on Kodak Tri-X for fluorescent images.

Samples for scanning electron microscopy observations were fixed in glutaraldehyde and dehydrated with ethanol, as above, except that $100 \%$ ethanol was replaced with amylacetate. All samples were critical-point-dried with $\mathrm{CO}_{2}$, mounted on silverpainted stubs, and sputter-coated with 40 to $50 \mathrm{~nm}$ of gold. Observations and photographs were made on a DS-130 scanning

Table 2. Effect of rubbing on percentage of peach and nectarine fruit with skin discoloration.

\begin{tabular}{lccccc}
\hline & \multicolumn{4}{c}{ Peaches } & Nectarine \\
\cline { 2 - 6 } & Flavor- & \multicolumn{3}{c}{ Elegant } \\
Treatment & crest & Suncrest & Lady & O'Henry & Fantasia \\
\hline Untreated $^{17.0 \mathrm{a}^{\mathrm{z}}}$ & $17.0 \mathrm{a}$ & $10.5 \mathrm{a}$ & $10.0 \mathrm{a}$ & $4.8 \mathrm{a}$ \\
Rubbed $^{\mathrm{y}}$ & $91.5 \mathrm{~b}$ & $80.0 \mathrm{~b}$ & $68.4 \mathrm{~b}$ & $85.0 \mathrm{~b}$ & $72.3 \mathrm{~b}$
\end{tabular}

${ }^{2}$ Mean separation within columns by the $\mathrm{F}$ test at $P \leq 0.05$. Each mean represents the average of three replications of 20 fruit.

${ }^{y}$ Rubbed gently with a clean dry washcloth immediately after harvest.

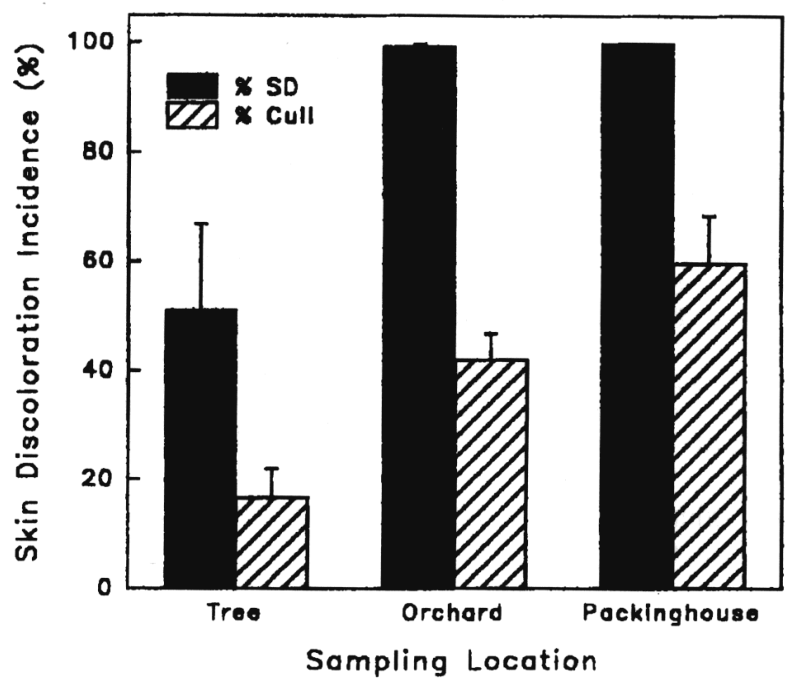

Fig. 1. Influence of harvest operations on skin discoloration incidence for 'Flavorcrest', 'Elegant Lady', and 'O' Henry' fruit collected at harvest: 1) directly from the tree and field-packed (tree), 2) after bin filling and transport in the orchard to the loading point (orchard), and 3) after handling and transport to the packinghouse (packinghouse). Each value represents an average of three cultivars using four replications of 18 fruit each. Arrows indicate standard error. 

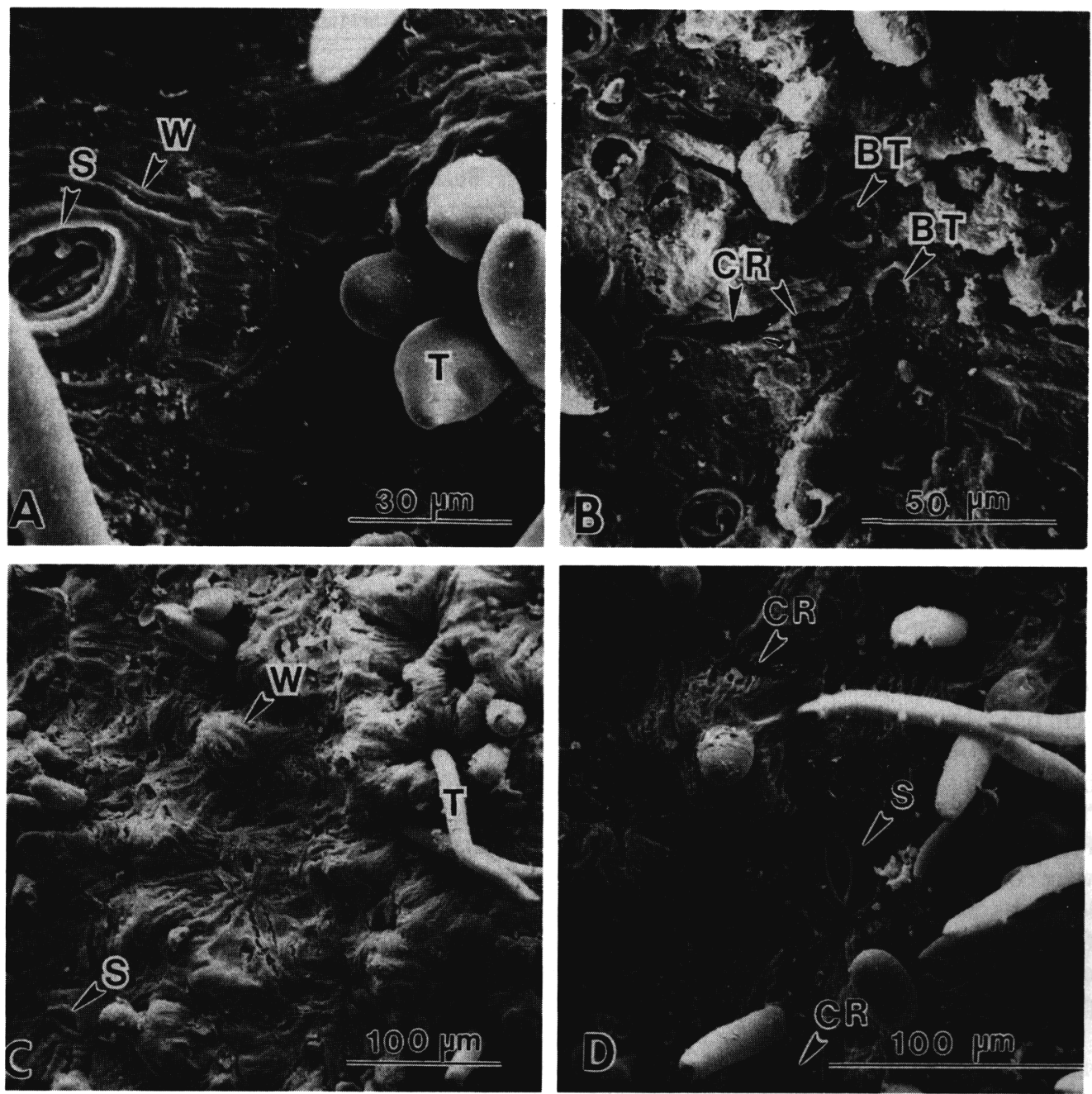

Fig. 2. Comparison of sound and damaged fruit tissue structure by scanning electron microscope. 'Flavorcrest', sound (A) and injured (B); 'Elegant Lady', sound (C) and injured (D); 'O'Henry', sound (E) and injured (F). Morphological features include $\mathbf{S}=$ stomate; $\mathbf{T}=$ trichome; $\mathbf{W}=$ wax; $\mathbf{C R}=$ cracking; $\mathrm{BT}=$ broken trichome; $\mathrm{AD}=$ abrasion damage.
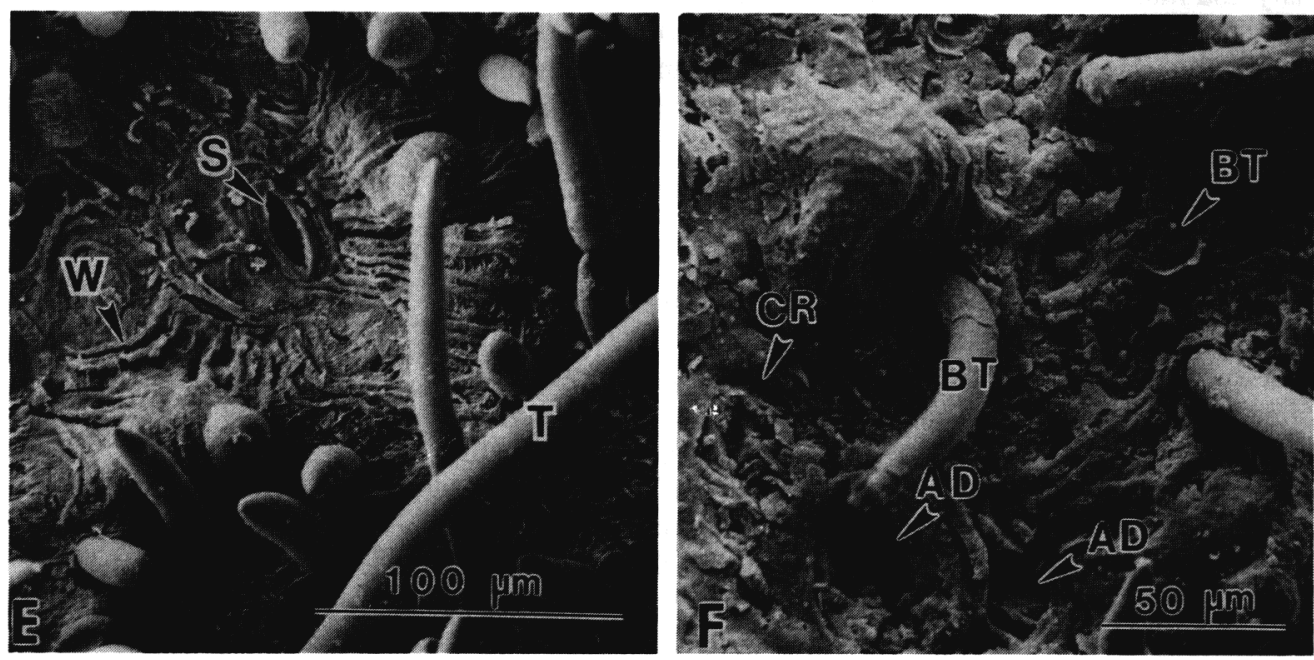

electron microscope (International Scientific Instruments, Inc., Santa Clara, Calif.) operated at $10 \mathrm{kV}$.

\section{Results}

Vibration damage. All the cultivars developed discolored spots (brown and/or black) after being subjected to dipping with or without vibration treatments. Vibration increased the incidence of SD two-fold or more in all cultivars (Table 1).

Abrasion damage. Rubbing the fruit immediately after harvest with a cloth induced a high incidence of SD (Table 2). The treatment increased incidence from 5- to 15-fold.

$S D$ occurrence during handling. Average incidence of SD increased dramatically with fruit handling after harvest (Fig. 1). High SD levels were detected on fruit sampled during harvest and before and after fruits were transported to the packinghouse. SD incidence on fruit picked directly into tray packs and transported gently to KAC was $42 \%, 42 \%$, and $29 \%$ for 'Flavorcrest', 'Elegant Lady', and 'O'Henry', respectively. Incidence before and after transport to the packinghouse was nearly $100 \%$. 

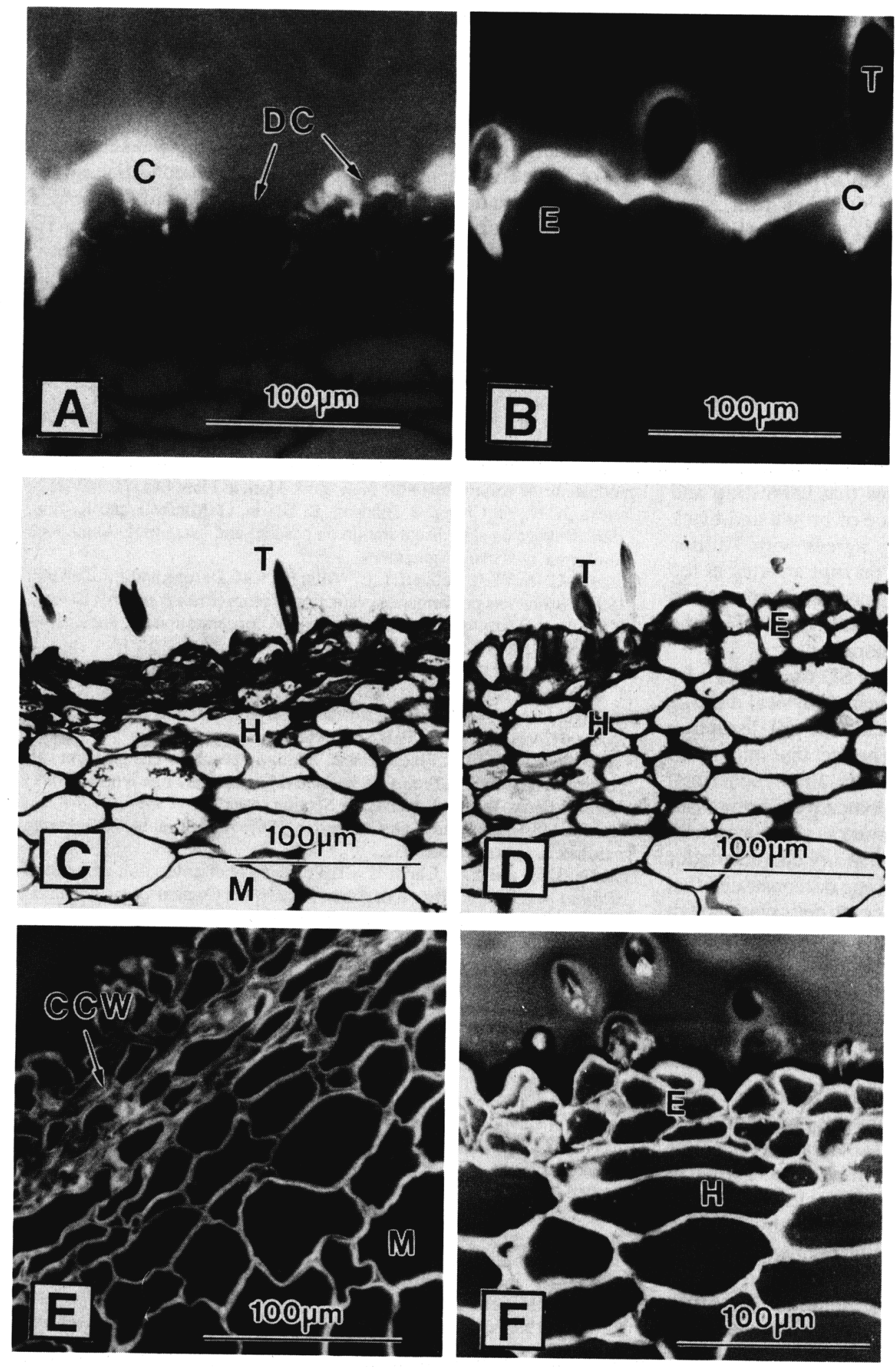

Fig. 3. Comparison of sound and damaged fruit cuticle, exocarp, and cell walls of 'O'Henry' using light microscopy plus different stains. (A) Damaged cuticle (nile red) on SD-injured tissue; (B) healthy cuticle (nile red) on sound tissue; (C) damaged exocarp (toluidine and safranin) on SD-injured tissue; (D) healthy exocarp (toluidine blue and safranin) on sound tissue; (E) healthy mesocarp cell walls (calcofluor) on SD-injured tissue; (F) healthy mesocarp cell walls (calcofluor) on sound tissue. $\mathrm{T}=$ trichome $\mathrm{C}=$ cuticle; $\mathrm{E}=$ epidermis; $\mathrm{H}=$ hypodermis; $\mathrm{DC}=$ disrupted cuticle; $\mathrm{CCW}$ = compressed cell walls; $\mathrm{M}=$ mesocarp.

High cull levels, up to $40 \%$, were measured after transport within and out of the orchard on 'Flavorcrest', 'Elegant Lady', and 'O'Henry' peaches. Fruit picked and packed directly in the orchard had $\approx 10 \%$ culls.

Anatomical studies. Fruit surface analysis on peach and nectarine fruit by SEM revealed marked surface differences between sound (Fig. 2 A, C, and E) and SD-injured peach and nectarine fruit (Fig. 2 B, D, and F). Examination of sound fruit skin tissue did not show any alteration in the fruit surface of 'Flavorcrest' (Fig. 2A), 'Elegant Lady' (Fig. 2C), and 'O'Henry' (Fig. 2E). Different degrees of cracking, from very minute to very extensive, were observed on the cuticle of 'Flavorcrest' (Fig. 2B), 'Elegant Lady' (Fig. 2D), and 'O'Henry' (Fig. 2F) fruit with SD. The presence of the cracks coincided with the appearance of the brown and/or black spots. Trichome and adjacent epidermal cells represented weak places on the surface of the peach, and most of the cracks were located in these regions.

Light microscopy of SD-injured fruit tissues stained with nile red always presented broken and interrupted cuticles for 'O'Henry' (Fig. 3A). In contrast, sound 'O'Henry' fruit tissue samples always 
exhibited continuous and thick fluorescence in the cuticle (Fig. 3B). Fruit tissue samples with SD stained with toluidine bluesafranin showed that all of the cells in the epidermis and hypodermis were completely collapsed for 'O'Henry' (Fig. 3C) compared to sound tissues for the same varieties (Fig. 3D). Specific cell wall observations with calcofluor stain pointed out differences in cell wall shape and integrity in the epidermal and hypodermis (exocarp) layers between SD (Fig. 3E) and sound 'O'Henry' fruit tissue (Fig. 3F). Epidermal tissue of fruit with SD showed cell walls compressed against each other and cytoplasm contents expelled and mixed. In sound and SD-injured peach and nectarine fruit samples, mesocarp cells located just beneath the hypodermis were not disrupted, nor was there any physical damage in the cell wall or cytoplasm of these cells.

\section{Discussion}

A high incidence of SD detected in the orchard and exacerbated by vibration and abrasion clearly indicates that harvesting and transport are responsible for the occurrence of brown and black spots (SD) on susceptible cultivars. This agrees with Phillips (1988), who reported that SD was visible on fruit arriving at the packinghouse. Cultural practices, including preharvest sprays and postharvest handling conditions, are all potential factors within the orchard environment involved in SD development.

Anatomical studies comparing sound and SD tissues done by SEM and LM indicated that very-low-intensity physical damage could induce brown and/or black spots because of cell disruption in the epidermal and hypodermal layers. The fact that injury was specific to the exocarp cells (cuticle, epidermis, and hypodermis) and that mesocarp tissue located below the exocarp cells remained sound and turgid indicated that abrasion injury is associated with SD. Similar types of visible and anatomical injury characteristics were induced by a rubbing treatment. Rubbing demonstrated that physical abrasion damage affecting just exocarp cells was enough to induce SD. Abrasion damage is restricted to exocarp cells (Sommer et al., 1960), and may be intensified by the presence of dirt on the fruit surface during postharvest operations. SD incidence was reduced when fruit were picked directly from the tree, packed, padded, and transported gently to the Postharvest Laboratory at KAC.

Anthocyanins and phenolic compounds are located inside vacuoles in the epidermal cells; the most abundant red pigment in peaches being cyanadin-3-glucoside (Hsia et al., 1965; Van Blaricom and Senn, 1967). This compound changes color when its environmental $\mathrm{pH}$ is modified, as do many anthocyanins (Hsia et al., 1965; Jurd and Asen, 1966). Under normal physiological conditions, the $\mathrm{pH}$ is between 2 and 3 and the pigment exhibits a red color. Jurd and Asen (1966), using an extracted and purified cyanidin-3-glucoside in aqueous solutions, reported that anthocyanin solutions were red at $\mathrm{pH} 1$ to 3 , colorless between $\mathrm{pH} 4$ and 5 , and purple between 6 and 7. Metallic ions in the presence of anthocyanin and phenolic compounds causes formation of dark pigments under normal plant tissue conditions and low $\mathrm{pH}$ (Asen et al., 1973; Hsia et al., 1965; Jurd and Asen, 1966). This phenomena is called copigmentation (Asen et al., 1973; Macheix et al., 1989; Osawa, 1985), and depends on the ratio of anthocyanins and phenolics to metallic ions. This ratio (copigments) can be changed by light, temperature, water stress, and pollution (Macheix et al., 1989; Salisbury and Ross, 1978), and may predispose peach fruits to SD. Rupture of epidermal cells from abrasion injury mixes cell components normally separated and thus induces an anthocyanin color change. Also, cuticle and epidermal wax disruption exposes epidermal cells to exogenous contamination (metallic ions, basic $\mathrm{pH}$ ), thus acting as a trigger to develop skin discoloration. Even air temperature, preharvest sprays, or high ozone levels (Crisosto et al., 1993) prior to harvest may modify fruit permeability and augment susceptibility to SD.

Whether or not these environmental factors may weaken the cuticle or induce endogenous chemical changes preconditioning the fruit to SD formation needs to be studied in more detail. Our results indicate that future research to understand peach and nectarine SD should be focused on the orchard rather than the packinghouse.

\section{Literature Cited}

Asen, S., K.H. Norris, R.N. Stewart, and P. Semeniuk. 1973. Effect of pH, anthocyanin, and flavonoid co-pigments on the color of statice flowers. J. Amer. Soc. Hort. Sci. 98:174-176.

Baumgarder, R. 1985. The peach skin discoloration problem. Natl. Peach Count. Proc. Nashville. p.25-37.

Ceponis, M.J., R.A. Capellini, and J.M. Wells. 1987. Disorders in plum, peach, and nectarine shipments to the New York Market. Plant Dis. 71:947-952.

Crisosto, C.H., G. Cheng, S. Johnson, B. Beede, G. Mitchell, and K. Day. 1992. Studies on skin discoloration on peaches and nectarines. Annu. Rpt. California Tree Fruit Agreement.

Crisosto, C.H., W.A. Retzlaff, L.E. Williams, T.M. DeJong and J.P. Zoffolli. 1993. Postharvest performance evaluation of plum (Prunus salicina Lindel., 'Casselman') fruit grown under three ozone concentrations. J. Amer. Soc. Hort. Sci. 118:497-502.

Denny, E.G., D.C. Coston, and R.E. Ballard. 1986. Peach skin discoloration. J. Amer. Soc. Hort. Sci. 111:549-553.

Hopfinger, J.A. 1985. Postharvest peach skin discoloration and its control. Rutgers Coop. Ext. Tech. Fact Sheet 06.

Hopfinger, J.A. and J.L. Frecon. 1985. Inking in peaches: The problem still persists in New Jersey. Proc. Cumberland-Shenandoah Fruit Worker Conf., Harpers Ferry, W.Va., Horticulture Section paper 11.

Hsia, C.L., B.S. Luh, and C.O. Chichester. 1965. Anthocyanins in freestone peaches. J. Food Sci. 30:5-12.

Hudson, D.E. and E.G. Christ. 1981. Postharvest discoloration of peaches (Prunus persica L.). Proc. 40th Annu. Natl. Peach Council Conv., Phoenix. p. 173-186.

Hughes, J. and M.E. McCully. 1975. The use of an optical brightener in the study of plant structure. Stain Technol. 50:319-329.

Lill, R.E., E.M. O'Donaghue, and G.A. King. 1989. Postharvest physiology of peaches and nectarines. Hort Rev. 11:413-452.

Luza, J.G., R. van Gorsen, V.S. Polito, and A.A. Kader. 1992. Chilling injury in peaches: a cytochemical and ultrastructural cell wall study. J. Amer. Soc. Hort. Sci. 117:114-118.

Jurd, L. and S. Asen. 1966. The formation of metal and "copigment" complexes of cyanidin-3-glucoside. Phytochemistry 5:1263-1271.

Macheix, J.J., A. Fleuriet, and J. Billot. 1989. Fruit Phenolics. CRC Press, Boca Raton, Fla.

Mitchell, F.G. and A.A. Kader. 1992. Factors affecting deterioration rates, p. 165-178. In: J.H. LaRue and R.S. Johnson (eds.). Peaches, plums and nectarines-growing and handling for fresh market. Univ. of California, Div. Agr. and Natural Resources, Oakland. Publ. 3331.

O'Brien, T.P. and C.E. McCully. 1981. The study of plant structure: Principles and selected methods. Termarcarphi Pty. Ltd., Melbourne, Australia.

Osawa, Y. 1982. Copigmentation of anthocyanins, p. 41-65. In: P. Markakis (ed.). Anthocyanins as food colors. Academic, New York.

Phillips, D.J. 1988. Reduction of transit injury-associated black discoloration of fresh peaches with EDTA treatments. Plant Dis. 72:118-120.

Ridley, J.D., L.O. VanBlaricom, and E.T. Simms. 1976. Postharvest treatment influences discoloration of fresh peaches. Coop. Ext. Serv., USDA Clemson Univ. Circ. 560.

Salisbury, F.B. and C.W. Ross. 1978. Plant physiology. 2nd ed. Wadsworth, Belmont, Calif. p. 302-303.

Sommer, N.F., F.G. Mitchell, R. Guillon, and D.A. Luvisi. 1960. Fresh fruit temperatures and transit injury. Proc. Amer. Soc. Hort. Sci. 76:156-162.

U.S. Department of Agriculture. 1987. U.S. Standards for grade of fresh fruit and vegetables. Food Safety and Quality Service, USDA, Washington D.C. Van Blaricom, L.O. and T.L. Senn. 1967. Anthocyanin pigments in freestone peaches grown in the southeast. J. Amer. Soc. Hort. Sci. 90:541-545. 